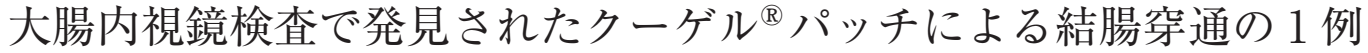

\author{
国立病院機構米子医療センター消化器外科 \\ 大谷裕谷口健次郎山本修 \\ 奈賀卓司杉谷篤
}

\begin{abstract}
症例は38歳の男性. 左鼠径ヘルニア嵌頓に対する緊急手術から約 2 年後, 検診で便潜 血反応の異常を指摘され, 数回の内視鏡検査の結果, S 状結腸内に過去の手術時に使用 されたクーゲル®パッチの一部が露出していることが判明した. 自覚症状は無かったが, 後に重篤な合併症を引き起こす可能性が高いと考え, 根治術を施行した. まず腹腔鏡に よる観察で, 左鼠径床と $\mathrm{S}$ 状結腸の強固な癒着を確認し, 剥離授動操作を進めた。 そし

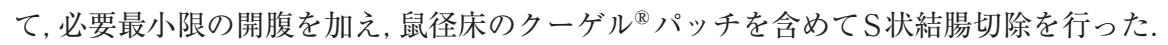
術後 1 年以上経過したが, トラブルなく経過している. クーゲル®゚゚ッチによる消化管 穿孔・穿通の症例報告は数例しか無く, 極めてまれなケースであると思われた，術者は， 術式や使用するメッシュの形状に関わらず, このような重篤な合併症が起こり得ること を念頭に置いて治療にあたるべきである。
\end{abstract}

索引用語：鼠径ヘルニア, 結腸穿通, クーゲル®゚゚ッチ

緒言

鼠経ヘルニア修復術では, 様々な形状のメッシュを 用いた術式が，今日の標準的治療法として確立されて いる，その背景には，従来から行われてきた組織結合 法 (pure tissue repair) ${ }^{1)}$ に比べて手技が簡便で，術 後疼痛や再発率の面で良好なアウトカムが報告されて いることがあると思われるが2) 4)，その一方でメッシ 工特有の術後合併症も少なからず報告されており，重 篤な合併症も5) 8) 散見される. 今回われわれは, 過去 に施行した手術時に使用されたメッシュが原因とな り，下部消化管への穿通をきたしたために手術を要し た 1 例を経験したので報告する.

\section{症例}

患者：38歳, 男性.

主訴：大腸癌検診時の便潜血反応異常.

既往歴 : 高血圧.

現病歴：2014年 7 月, 左鼠径部痛にて当院救急外来 を受診した。画像検査にて大量の大網が嵌頓している ことがわかり（Fig. 1), 左外鼠径ヘルニア嵌頓と診

2018年 8 月16日受付 2018年11月22日採用

〈所属施設住所〉

下683-0006 米子市車尾 4-17-1
断して用手的還納を試みたが，整復できず緊急手術を 施行した。手術は腹腔鏡下に進めたが，嵌頓した大網 の処理に難渋し, 鼠径部切開法に術式を変更した。へ ルニア門は長径約 $3 \mathrm{~cm}$ で, クーゲル®パッチ（Sサイ ズ）を用いて修復した (Fig. 2). 閉創前に腹腔鏡で 観察し,メッシュが剥離腔で適切に広がっていること を確認した。その後の経過は良好で, 術後 3 日目に退 院した. 術後の定期経過観察中（退院後10日，1 力月， 半年）には特に問題は確認されなかった，初回手術か ら約 2 年後, 大腸癌検診で便潜血反応の異常を指摘さ れ，当院で施行された大腸内視鏡検査で，S状結腸の 粘膜不整領域が問題となった．生検では悪性所見は指 摘されなかったが, 肉眼的所見が問題視され, 後日計 3 回の大腸内視鏡検査が施行された (Fig. 3a〜c). 初回検查から半年後, S 状結腸内にクーゲル ${ }^{\circledR}$ パッチ の一部と思われる構造物が露出していることが判明 し，当科へ紹介された。

現症：身長 $182 \mathrm{~cm}$, 体重 $93 \mathrm{~kg}$, 体温 $36.2^{\circ} \mathrm{C}$, 脈拍 72 回/分, 血圧168/88mmHg. 左鼠径部および臍部に手 術創部瘕痕を認めたが，同部位やその近傍に発赤，圧 痛, 瘦孔形成などを認めなかった。

血液・生化学検査所見：明らかな異常值を認めなか った. 


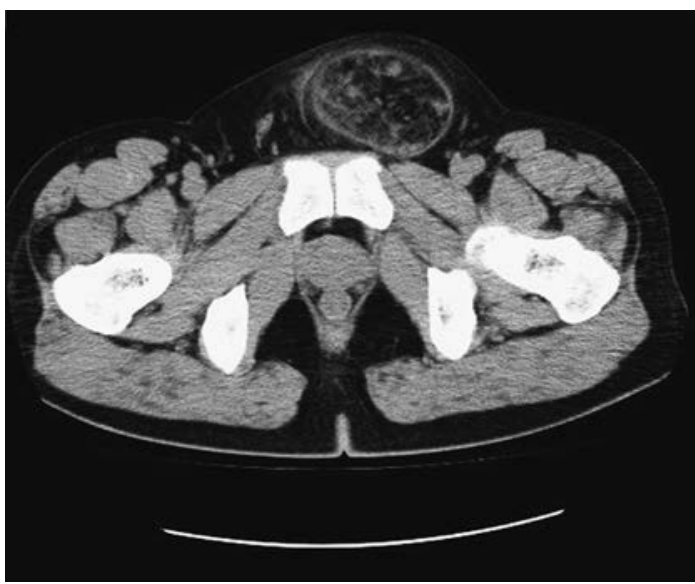

Fig. 1 初回手術前の腹部単純 CT 検査像 : 左外鼠径へル ニア嵌頓（ヘルニア内容は大網）と診断した。用手還 納を試みたが不成功に終わった。

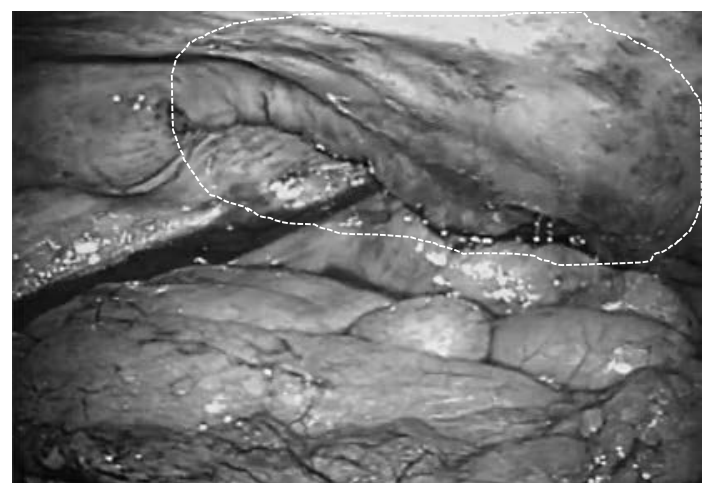

Fig. 2 初回手術所見：鼠径部切開前方到達法でクーゲ ル®パッチを用いて修復 (点線部) した後, 腹腔内か ら観察を行って適切に修復されていることを確認し た。
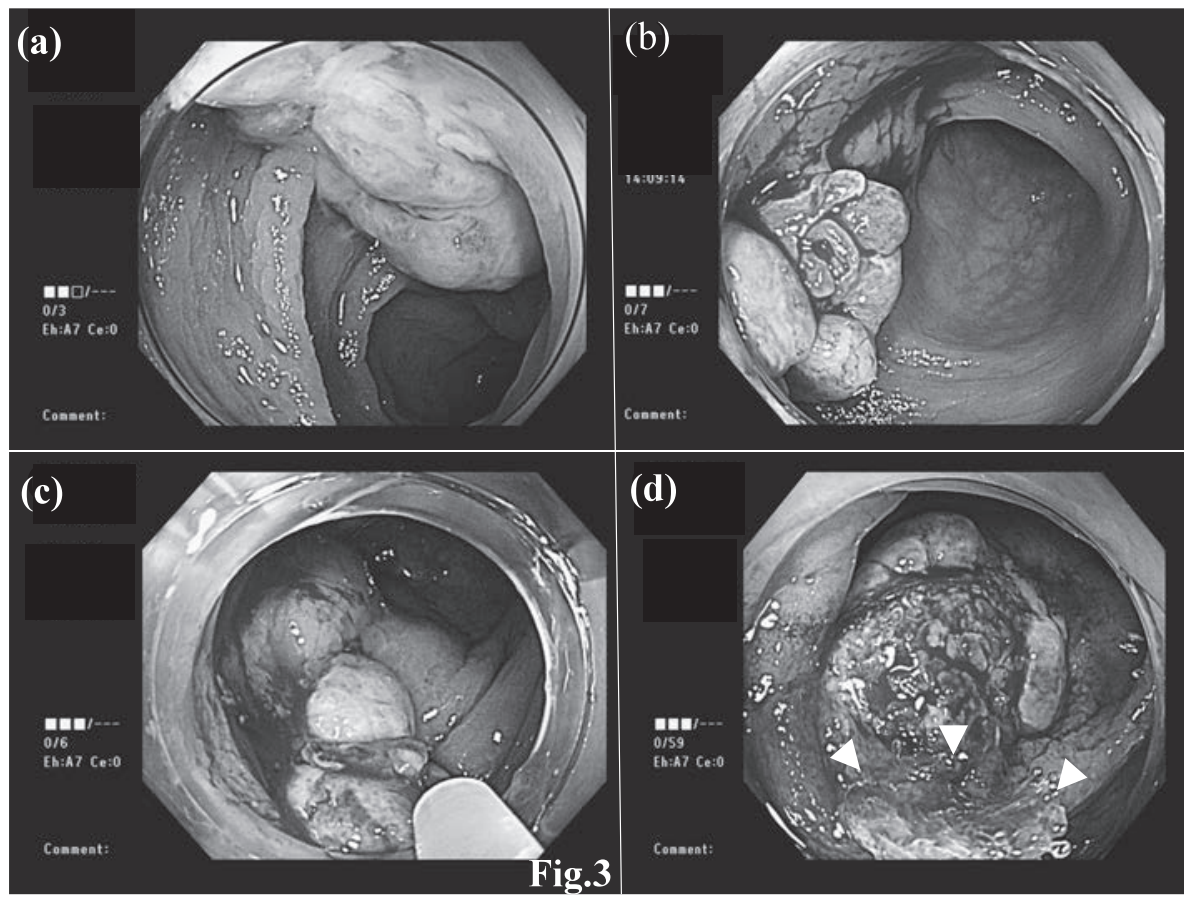

Fig. 3 下部消化管内視鏡検査像

$\mathbf{a} \sim \mathbf{c}$ : 初回検査から 1 2 カ月毎に検査が行われた. 粘膜不整域からの生検では悪性細胞は 検出されなかった.

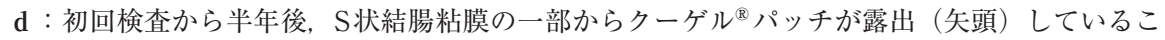
とが判明した。 

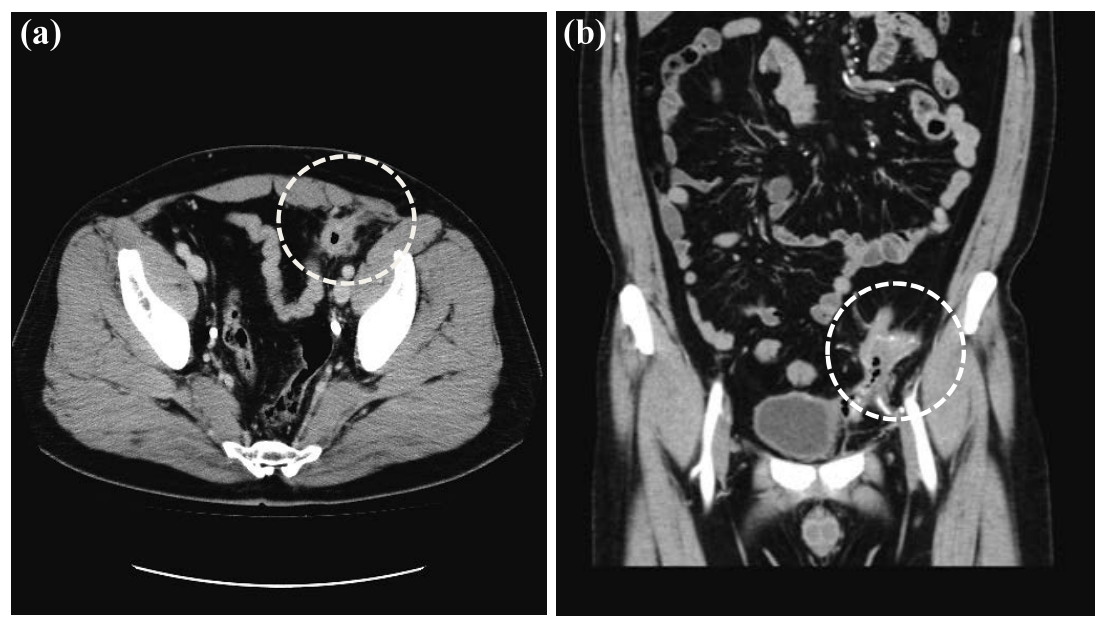

Fig. 4 腹部造影 CT 検查像

$\mathrm{a}$ ：左下腹壁に辺縁に造影効果を伴う不整形除影（点線）を認める。

b : 不整形陰影は内部にエアーを伴い, S 状結腸の一部と膀胱左側壁を巻き达むように 存在していることが分かった (点線).

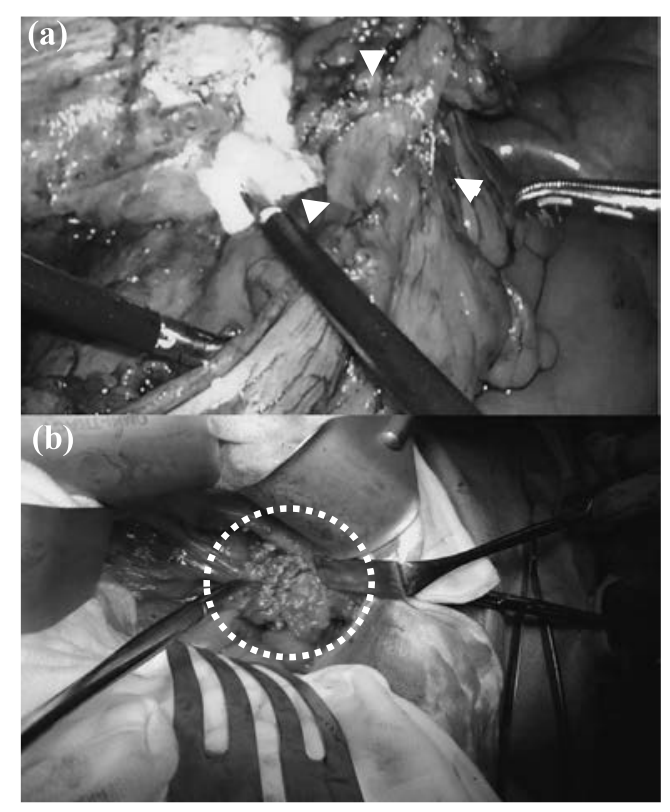

Fig. 52 回目手術所見

$\mathrm{a}$ : 腹腔内からの観察で, $\mathrm{S}$ 状結腸の一部が左鼠 径床に強固に癒着していることが分かった（矢 頭).

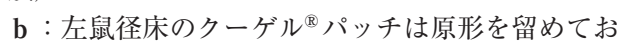
らず (点線部), 全て切除するのに難渋した.
腹部造影 CT 検査 : 下行結腸 S 状結腸移行部付近か ら膀胱左側壁前部に連続する, 不整形の陰影を認めた。 造影された陰影内部にはエアーを認め, 消化管と穿通 している可能性があると考えられた（Fig. 4a，b）.

下部消化管内視鏡検査 : S 状結腸粘膜の粘膜不整部 内にクーゲル®パッチの一部と思われる構造物を認め た（Fig. 3d）。粘膜不整部分からの生検で炎症性細胞 が散在する肉芽組織と診断された.

以上の検査結果より, 過去に使用されたクーゲルパ ッチが $\mathrm{S}$ 状結腸の一部と癒着して穿通していると診断 した，穿通による慢性炎症性変化が，後の腹腔内膿瘍 や膀胱穿通などの原因となる可能性が高いと考え, 根 治術を施行した.

手術所見：まず，臍部のトロッカーより腹腔鏡を挿 入して腹腔内を観察し, 左鼠径床と $\mathrm{S}$ 状結腸の強固な 癒着を確認した (Fig. 5a). 次に, 左右側腹部から計 4 個のトロッカーを挿入し, 癒着部の口側および肛門 側の剥離授動操作を十分に行った後, 一旦気腹を止め, 下腹部正中切開をおいて鼠径床のクーゲル®パッチを 含めて S 状結腸切除を行った（Fig. 5b). 腸管は手綘 い端々吻合にて再建し，鼠径床の修復は行わず，持続 吸引用ドレーンを留置して手術を終了した.

術後経過：術後に心配された創部や鼠径床の感染は 発生せず, 術後 12 日で退院した. 術後 1 年が経過した が, 創部や腹腔内感染, 鼠径ヘルニア再発などをきた すこと無く経過している. 
Table 1 鼠径ヘルニア修復術時に使用されたメッシュに関連した消化管穿孔・穿通例（本邦報告例）

\begin{tabular}{|c|c|c|c|c|c|c|c|c|c|c|c|c|}
\hline 報告者 & 報告年 & 年齢 & 性別 & 部位 & 発症までの期間 & 穿孔·穿通部位 & 使用メッシュ & 診断契機 & 術式 (2回目) & 腸管切除 & メッシュ除去 & 後壁補強 \\
\hline 園原16) & 2011 & 69 & M & 右 & 12日 & 小腸 & proloop & 腸閉塞 & 開腹 & $(+)$ & $(+)$ & $(-)$ \\
\hline 塩谷 ${ }^{17)}$ & 2010 & 69 & M & 右 & 2 年 & 盲腸 & $\mathrm{KP}$ & 下腹部腫瘤 & 開腹 & $(+)$ & $(+)$ & $(-)$ \\
\hline 石岡18) & 2013 & 82 & $\mathrm{~F}$ & 右 & 5 年 & S 状結腸, 膀胱 & MP & 下腹部痛 & 開腹, 鼠径部切開 & $(+)$ & $(+)$ & 外腹斜筋授動 \\
\hline 坂田 ${ }^{19)}$ & 2012 & 57 & M & 右 & 7年 & 盲腸 & MP & 鼠径部腫脤 & 開腹, 鼠径部切開 & $(+)$ & $(+)$ & $(-)$ \\
\hline Zuvela ${ }^{15)}$ & 2012 & 42 & M & 右 & 6年 & 虫垂 & PHS & 鼠径部膿瘍 & 鼠径部切開 & $(+)$ & $(+)$ & McVay法 \\
\hline Zuvela $^{15)}$ & 2012 & 76 & M & 右 & 7年 & 虫垂 & PHS & 鼠径部痛 & 鼠径部切開 & $(+)$ & $(+)$ & McVay 法 \\
\hline Zuvela $^{15)}$ & 2012 & 60 & M & 左 & 8年 & S 状結腸 & PHS & 鼠径部膘瘍 & 鼠径部切開 & $(-)$ & $(+)$ & McVay 法 \\
\hline 原内 ${ }^{20)}$ & 2014 & 70 & M & 左 & 5力月 & S状結腸 & UHS & 内視鏡異常所見 & 開腹, 鼠径部切開 & $(+)$ & $(+)$ & $(-)$ \\
\hline 田島 $\mathrm{G}^{21}$ & 2015 & 80 & M & 左 & 10年 & S 状結腸 & MP & 鼠径部膿瘍 & 開腹, 鼠径部切開 & $(+)$ & $(+)$ & $(-)$ \\
\hline 出口22) & 2014 & 69 & M & 左 & 3年 & S 状結腸, 膀胱 & MP & 鼠径部膿瘍 & 開腹, 鼠径部切開 & $(+)$ & $(+)$ & $(-)$ \\
\hline 伊藤23) & 2015 & 76 & M & 左 & 13年 & S 状結腸 & MP & 鼠径部痛 & 開腹, 鼠径部切開 & $(+)$ & $(+)$ & $(-)$ \\
\hline 島村24) & 2015 & 62 & $\mathrm{~F}$ & 左 & 9年 & 小腸 & MP & 鼠径部痛 & 開腹 & $(-)$ & $(+)$ & $(-)$ \\
\hline 上原6) & 2017 & 63 & M & 左 & 10年 & S 状結腸 & PHS & 鼠径部痛 & 腹腔鏡補助下 & $(+)$ & $(+)$ & Bassini法 \\
\hline 自験例 & 2019 & 38 & $\mathrm{M}$ & 左 & 2 年 & S 状結腸 & $\mathrm{KP}$ & 便潜血異常 & 腹腔鏡補助下 & $(+)$ & $(+)$ & $(-)$ \\
\hline
\end{tabular}

\section{考察}

鼠径へルニア修復術において，メッシュを用いた術 式は, 組織に過剰な緊張を与えないtension free 法2) 4) として20世紀末から急激に普及し，標準術式としての 地位を確固たるものにしている. 従来から行われてきた組 織結合法に比べ, 術後疼痛や再発率の面で優り ${ }^{9)}$ 12), 手術の簡便性や術後QOLの高さから日㷌り手術の世界 でも頻用される術式である。 その一方, QOL低下に つながる注意すべき合併症も諸家が報告しており，使 用したメッシュの形状や留置場所に関連した特徵的な 合併症5) 8)13) 15) が散見される. その多くはメッシュ の感染に関連したもので，それをきっかけに膿瘍や瘻 孔形成が発生している. 今回われわれが経験した, 鼠 径へルニア修復術に関連したメッシュによる消化管穿 孔・穿通の報告は少なく, 医学中央雑誌Web版にて「鼠 径ヘルニア」「消化管穿孔・穿通」をキーワードに 1983年～2017年を検索（会議録を除く）したところ，

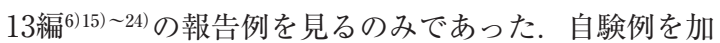
えた14例について検討すると, 消化管穿孔・穿通の多 くはPerfix plug ${ }^{19) \sim 24)}$ やProloop ${ }^{16)}$ などプラグ形状のメ ッシュを用いた術式に合併しており，次いでPHS ${ }^{6) 15)}$

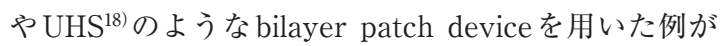
多くみられ，われわれが用いたクーゲルパッチに関 連した報告は 1 例のみ ${ }^{17)}$ であった。左鼠径へルニアの 術後 (8 例), S 状結腸の穿孔・穿通 (8 例), が多い 傾向が見られたが, これには, S 状結腸の生理的癒着
との関連が考えられる（Table 1)。初回手術から発 症までの期間は，手術後極早期（12日）のもの ${ }^{16)}$ から 比較的長期間（13年）のもの ${ }^{23)}$ が報告されており，生 体内で分解されることが無いメッシュを用いたtension free repairの特徴を示した結果と解釈できる. 治 療法であるが，全例が外科手術を選択しており，術式 はほぼ開腹か鼠径部切開法で，腹腔鏡を補助的に用い た例は, 自験例以外には上原ら ${ }^{6)}$ の 1 例のみであった. 基本的にメッシュは除去されているが, 部分的除去し かできなかったもの ${ }^{16) 20)}$ や除睪術を要した15)ものも報 告されている，後壁補強はほぼ $1 / 3$ で施行されてい るが，それらは組織結合法に準じて行われ，メッシュ を用いた例は 1 例もなかった。

本症例の消化管穿通の原因について考察する．本症 例では, 消化管穿通と診断する約 2 年前に鼠径へルニ ア嵌頓に対して腹腔鏡補助下手術（腹腔鏡による観察 下に鼠径部切開前方到達法を施行)を施行しているが, その際にヘルニア囊を開放して綘合閉鎖する過程で, $\mathrm{S}$ 状結腸壁近傍の腹膜を縫合したため, 縫合した腹膜

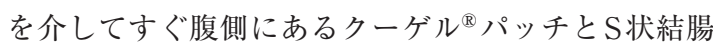
との慢性的密着状態を作ってしまった可能性がある. 初回手術時のビデオ画像を確認すると, 左鼠径ヘルニ ア囊の内側にかなり近接した $\mathrm{S}$ 状結腸を認めたが，仮 にヘルニア囊を開放しなかったとしてもクーゲルパ ッチと S 状結腸の位置関係はかなり近接した状態にあ ったと思われ，ヘルニア囊の開放や縫合閉鎖が，クー 


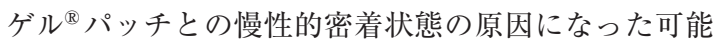
性は憶測の域を脱しない. 上原ら ${ }^{6)}$ は, PHSを用いた 手術後10年目に発症した $S$ 状結腸穿通の報告の中で, $\mathrm{S}$ 状結腸の生理的癒着部にPHSの underlay patch が展 開されたことで，S状結腸壁への永続的な圧迫刺激を 与え, それに起因する線維化によって腸管壁が漿膜方 向へ毫引されたことが穿通の原因となった可能性を考 察しており，自験例の発症過程を考察する上で興味深 い.メッシュによる消化管穿孔・穿通の報告で考察さ れている原因として，その形状がよく挙げられている が, これについては, 以前から Perfix plugに代表さ れる，腹腔内へ突出する形で腹膜の上に配置されるメ ッシュについての報告が多く, PHSやUHSを用いた 手術後の報告がこれに続く理由も，これらのメッシュ が有するシリンダー形状の部分が腹腔内へ突出する形 になっていることが関係しているものと推測される.

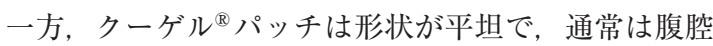
内に対して突出する部分を有さないが, 変形が起こる と腹腔内へ突出し, Perfix plugを用いた術式で消化 管穿孔・穿通が生じた場合と同様の環境が成り立つも

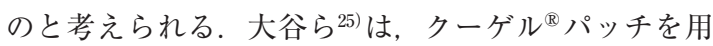
いた手術後に発症した癒着性イレウスの報告の中で, メッシュ変形が腹腔内藏器との持続的な接触状態の原 因となり，それが癒着を誘発した可能性を考察してい る.また塩谷ら ${ }^{17)}$ は, メッシュの露出が腹腔内臓器と の癒着を誘発して瘦孔形成の原因となった可能性を述 べており，鈴木ら ${ }^{26)}$ は, メッシュの形状に関わらず㾞 孔形成や癒着をきたす可能性があることを注意喚起し ている. 以上より, 自験例の消化管穿通の原因として は,（1）S 状結腸に極めて近接した部分でクーゲル ${ }^{\circledR}$ パッチが持続的な接触状態に置かれた,（2）剥離腔 の中でクーゲルパッチが不十分に展開され， S 状結 腸に対して面では無く点で長時間接触した状態になっ た，の 2 点が考えられる．穿孔・穿通の本邦報告例の 結果を見ると，手術操作部近傍の憩室の存在 $\left.{ }^{17)} 18\right) 22$ 24) やステロイド内服の既往 ${ }^{23)}$ な゙が発症に関わった可能 性も示されているが，使用するメッシュの形状や，鼠 径部へのアプローチ法に関わらず，メッシュを適切な 位置に変形無く配置することが，同様の合併症を発生 させないために最も重要であると思われた

\section{結語}

クーゲル ${ }^{\circledR}$ パッチを用いたヘルニア修復術後約 2 年 で発症したS状結腸穿通の 1 例を経験した。術者は, 術式や使用するメッシュの形状に関わらず, このよう
な重篤な合併症が起こり得ることを念頭に置いて治療 にあたるべきである。

なお, 本論文の要旨は第14回中国四国ヘルニア手術 研究会（2017年 7 月, 広島）にて報告した.

利益相反：なし

\section{文献}

1) Hay JM, Boudet MJ, Fingerhut A, et al : Shouldice inginal hernia repair in the male adult : the gold standard? A multicenter controlled trial in 1578 patients. Ann Surg $1995 ; 222$ : 719-727

2) Lichtenstein IL, Shulman AG, Amid PK, et al : The tension-free hernioplasty. Am J Surg $1998 ; 157: 188-193$

3) Rutkow IM, Robbins AW : "Tension-free” inguinal herniorrhaphy : a preliminary report on the “mesh plug” technique. Surgery $1993 ; 114: 3-$ 8

4) McGillicuddy JE : Prospective randomized comparison of the Shouldice and Lichtenstein hernia repair procedures. Arch Surg 1998 ; 133 : 974 978

5) Benedetti M, Albertario S, Niebel T, et al : Intestinal perforation as a long-term complication of plug and mesh inguinal hernioplasty : case report. Hernia $2005 ; 9$ : $93-95$

6）上原拓明, 山崎俊幸, 岩谷 昭他：鼠径ヘルニア 術後10年目にS 状結腸穿通をきたし腹腔鏡補助下 のメッシュを除去した 1 例. 日内視鏡外会誌 $2017 ; 22: 87-93$

7）江村正博, 新保正貴, 鈴木規之他：鼠径ヘルニア 修復術のメッシュプラグ迷入により生じた膀胱結 石. 臨泌 $2009 ; 63: 457-459$

8）楠部潤子, 中原雅浩, 福田敏勝他: Kugel 法施行後, 術後動脈性出血をきたした鼠径へルニアの 1 例. 日臨外会誌 $2009 ; 70: 1232-1235$

9) Butters M, Redecke J, Koninger J : Long-term results of a randomized clinical trial of Shouldice, Lichtenstein and transabdominal preperitoneal hernia repairs. Br J Surg 2007 ; 94 : 562 565

10) Liem MS, van Duyn EB, van der Graaf $Y$, et al ; Coala Trial Group : Recurrence after conventional anterior and laparoscopic inguinal hernia repair : a randomized comparison. Ann Surg 2003 ; 237 : $136-141$

11) Nordin P, Bartelmass P, Jansson C, et al : randomized trial of Lichtenstein versus Shouldice hernia repair in general surgical practice. $\mathrm{Br} \mathrm{J}$ Surg $2002 ; 89: 45-49$

12) Tschudi JF, Wagner M, Klaiber C, et al : Ran- 
domized controlled trial of laparoscopic transabdominal preperitoneal hernioplasty vs Shouldice repair. Surg Endosc $2001 ; 15$ : 1263 - 1266

13）小林真一郎, 谷村葉子, 高野 学他: 鼠径ヘルニ ア術後 5 年以上経過後の遅発性メッシュ感染の 2 例. 日臨外会誌 $2010 ； 71: 560-563$

14）渋谷雅常, 寺岡 均, 坂下克也他：鼠径ヘルニア 術後 1 年目に発症した遅発性メッシュ感染の 1 例. 手術 $2011 ; 65: 1849-1852$

15) Zuvela M, Krivokapic Z, Galun D, et al : Rare late mesh complications following inguinal prolene hernia system hernioplasty : report of three cases. Surg Today $2012 ; 42: 1253-1258$

16）園原史訓, 原田明生, 小西 滋：鼠径ヘルニア修 復に用いたproloopの小腸穿通でイレウスを生じ た 1 例. 日外科系連会誌 $2011 ; 35: 895-898$

17）塩谷 猛, 野村 聡, 渡邊善正他：Kugel法によ る鼠径ヘルニア術後に大腸穿通を来した盲腸喤室 炎の 1 例. 日消外会誌 $2010 ； 43: 90-94$

18）石岡興平, 小山文一, 中川 正他: 右鼠径ヘルニ ア術後メッシュ感染に対する外腹斜筋授動一期的 腹壁再建の 1 例. 手術 $2013 ; 67: 1685-1688$

19）坂田宏樹, 小山広人, 豊田宏之他：鼠径ヘルニア 修復術 7 年後にメッシュプラグによる盲腸穿通をき
たした 1 例。日臨外会誌 $2012 ； 73: 3187-3191$

20）原内大作, 宇山攻, 島田良明他：鼠径ヘルニア 術後に合併症を起こした 3 例. 高知県医師会医誌 $2014 ; 19: 205-210$

21）田島ジェシー雄, 加藤浩樹：メッシュプラグによ る鼠径ヘルニア術後にS 状結腸穿通を来した 1 例. 日外科系連会誌 $2015 ; 40 ： 286-292$

22）出口幸一, 玉川浩司, 岩瀬和裕他：メッシュプラ グに起因すると考えられた S 状結腸㮩室炎穿孔の 1 例. 日外科系連会誌 $2014 ; 39: 228-233$

23）伊藤慎吾, 高橋 玄, 小島 豊他：鼠径ヘルニア 術後のメッシュプラグ感染を介して S 状結腸皮虐 㿉をきたした 1 例。 日腹部救急医会誌 2015 ; $35: 441-444$

24）島村隆浩, 星川真有美, 前間 篤他：メッシュプラ グを用いた再発鼠径ヘルニア術後に遅発性小腸穿通 を来した 1 例. 日外科系連会誌 $2015 ； 40 ： 885$ $-890$

25）大谷 裕, 国末浩範, 太田徹哉他：鼠径ヘルニア に対するKugel法術後に発症した絞扼性イレウス の 1 例. 日臨外会誌 $2008 ; 69: 833-837$

26）鈴木崇史, 市川伸樹, 柏倉さゆり他：鼠径ヘルニア 術後に虫垂・膀胱と瘦孔形成した遅発性メッシュ 感染の 1 例. 日臨外会誌 $2016 ; 77: 2303-2310$

\title{
DIAGNOSIS OF A CASE OF COLONIC PERFORATION CAUSED BY A KUGEL PATCH USING FIBEROPTIC ENDOSCOPY
}

\author{
Yuu OHTANI, Kenjiro TANIGUCHI, Osamu YAMAMOTO, \\ Takuji NAKA and Atsushi SUGITANI \\ Department of Gastroenterological Surgery, National Hospital Organization Yonago Medical Center
}

A 38-year-old male was urgently admitted to our department with an incarcerated left inguinal hernia. Reduction was unsuccessful, and emergency surgery was performed the day after admission. The surgery was performed laparoscopically, but because it was difficult to manage the incarcerated omentum, we converted to an inguinal incisional approach. About two years later, the patient had a positive fecal occult blood test, and fiberoptic colonic endoscopy was performed at our hospital. The endoscopy showed a structure that seemed to be part of a Kugel patch in the sigmoid colon. There were no subjective symptoms or abnormal blood tests. However, we assumed that changes due to chronic inflammation would probably cause problems later. Therefore, we performed curative surgery with laparoscopic assistance. Initial laparoscopic observation confirmed adhesions between the left inguinal bed and sigmoid colon. We peeled away the adhesions at the top and bottom of the patch, and then performed open sigmoidectomy, including peeling of the prosthesis from the inguinal bed. We then reconstructed the digestive tract using end-to-end anastomosis. Despite our concerns, no infections occurred in the wound or inguinal bed, and the patient was discharged 12 days after the operation. More than 1 year has passed since the surgery without problems. As only a few cases of gastrointestinal perforation caused by a Kugel Patch have been reported, this appears to be an extremely rare case. Surgical management should take into consideration the possibility of serious complications, regardless of the type of procedure or prosthesis.

Key words : inguinal hernia, colonic perforation, Kugel patch 